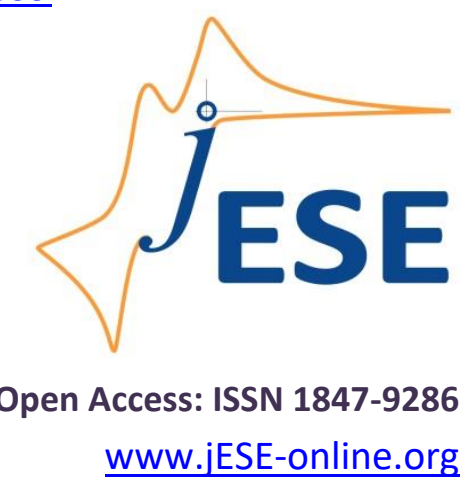

Review

\title{
An overview of recent developments of carbon-based sensors for the analysis of drug molecules
}

\author{
Pemmatte A. Pushpanjali, Jamballi G. Manjunatha ${ }^{\bowtie}$ and Nagarajappa Hareesha \\ Department of Chemistry, FMKMC College, Madikeri, Mangalore University Constituent College, \\ Karnataka, India
}

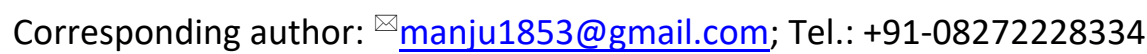

Received: April 21, 2021; Revised: July 5, 2021; Accepted: July 6, 2021; Published: July 20, 2021

\begin{abstract}
This review summarizes some recent developments in the fabrication of modified sensors and biosensors using carbon-based materials. The great potential of carbon-based electrodes as sensing platforms is exciting due to their unique electrical and chemical properties, high accessibility and high biocompatibility. Carbon-based materials are particularly interesting due to almost infinite possibility of their functionalization with a wide variety of organic molecules, biologically important compounds and pharmaceuticals. This review is specifically focused on recent developments in the utilization of various carbonbased electrodes as sensing devices for the electrochemical investigation of drug molecules. Various voltammetric techniques considered in this effort include linear sweep voltammetry (LSV), cyclic voltammetry (CV), differential pulse voltammetry (DPV), square wave voltammetry (SWV), and square wave adsorptive stripping voltammetry (SWAdSV). The carbonbased electrode materials considered in this review comprise carbon paste, carbon nanotubes, graphite, graphene, and glassy carbon. The analytes chosen are some routinely used drugs such as paracetamol (PC), diclofenac sodium (DCF), 5-fluorouracil (5-FU), cetirizine (CTZ) and salbutamol (SAL). All here reported sensing electrodes produced very good results in electrochemical investigations of these drug molecules.
\end{abstract}

\section{Keywords}

Electrochemical investigations; modified carbon electrodes; sensing device; voltammetry techniques

\section{Introduction}

Drugs are chemical substances of specific structures, which administered to a body, interact and bind with certain proteins and cells and affect physiological function by altering the biological structure. This is the common thought staying behind all medicine. There are no drugs, however, being so specific to interact with a certain type of cell or protein, what is the main reason of various 
side effects [1]. Since drugs are routinely used for treatments of various diseases, it is generally considered very essential to develop a convenient method for their determination. Among various analytical techniques, electroanalytical techniques possess high flexibility, sensitivity, simplicity, rapidity, and are easy to handle. Under accessible operating conditions, these techniques are found appropriate for the analysis of food, pharmaceutical and clinical samples [2-5].

Most of the analytical methods for investigations of drug molecules already reported in the literature, such as high-performance liquid chromatography (HPLC) [6], capillary zone electrophoresis [7], fluorescence spectroscopy [8], and spectrophotometry [9], are expensive compared to electroanalytical methods. All these methods, however, are inappropriate for routine analyses because they need expensive instrumentation, tedious sample preparation, complex pretreatment, solvent extraction, elongated analysis time, derivatization, and expert analysts handling with a complex instrumentation $[10,11]$. The electroanalytical performance is the most appropriate analytical platform for sensitive and selective investigation of commercial and real drug samples. Electroanalytical methods use easy instrumentation and show fast responses. They are also highly sensitive, steady, simple, accurate, specific, economical and need small amounts of sample [12-14].

In the context of electroanalytical methods aimed to the analysis of drug molecules, the most important topic is preparation of modified sensing electrodes via numerous modulating mediators and methods. Such sensor electrodes show the boosted sensitivity and respectable steadfastness for the analysis of drug molecules using some specific electrochemical methods [15-18]. The modification of electrode surfaces has usually been done by some important methods such as electro-deposition, drop-casting, and electrochemical polymerization. These methods need surface modifying agents such as metal-based nanomaterials, carbon-based nanostructures, organic molecule functionalized nanostructures, surfactants (anionic, cationic and nonionic), dyes and organic molecules (like amino acids, vitamins, neurotransmitters, etc.) [19-21]. The surface modification of bare electrode materials enhances the electrochemical sensing activity due to application of elevated catalytic action, and generates more active sites, higher electron affinity, lower ionization potential, and higher electronic and ionic conductivity [23-25].

Electroanalytical approach with carbon-based modified electrodes is extensively used in the exploration of new drug compounds. In that, voltammetric and amperometric techniques are usually used for recording of current-voltage responses of drug molecules at fabricated electrode surfaces [26-28]. Depending on the mode of potential change, voltammetric techniques include various types such as linear sweep voltammetry (LSV), cyclic voltammetry (CV), normal pulse voltammetry (NPV), differential pulse voltammetry (DPV), differential pulse adsorptive stripping voltammetry (DPAdSV), square wave voltammetry, (SWV), and square wave adsorptive stripping voltammetry (SWAdSV).

Carbon-based electrodes are currently in widespread use in electroanalytical chemistry for many different applications. This is due to their large potential window, low cost, rich surface chemistry, low background current, chemical inertness, and congruity [29-35]. Carbon is a distinctive and necessary element in our world. Remarkably, for the human body, it is the second most common element after oxygen [36]. Carbon science is very popular today in the field of nanoscience, materials science, engineering and technology. Carbon nanostructures are considered as different low-dimension allotropes of carbon including graphite, activated carbon, carbon nanotubes (CNTs), and graphene $[37,38]$. Most of recently reported data on the application of these carbon materials for the electrochemical sensing of some commonly applied drug molecules (paracetamol, diclofenac, 5-fluoro uracil, cetirizine, and salbutamol), are discussed in this review. 


\section{Carbon-based sensors for electrochemical study of drug molecules}

\section{Electrochemical analysis of paracetamol}

Paracetamol (PC) is one of the most frequently using painkillers to relieve pain, and it shows both analgesic and antipyretic activities [39]. Electrochemical sensing of PC is known to be very interesting due to its routine usage for various treatments. Usually, PC has no adverse side effects as it is entirely metabolized into inactive metabolites, which can be quickly excreted by urine [40]. However, the overdose of this drug may lead to inflammation of the pancreas, depletion of glutathione, fulminating hepatotoxicity, kidney problems and nephrotoxicity [41]. The possible redox reaction of PC at an electrode surface is shown in Scheme 1.

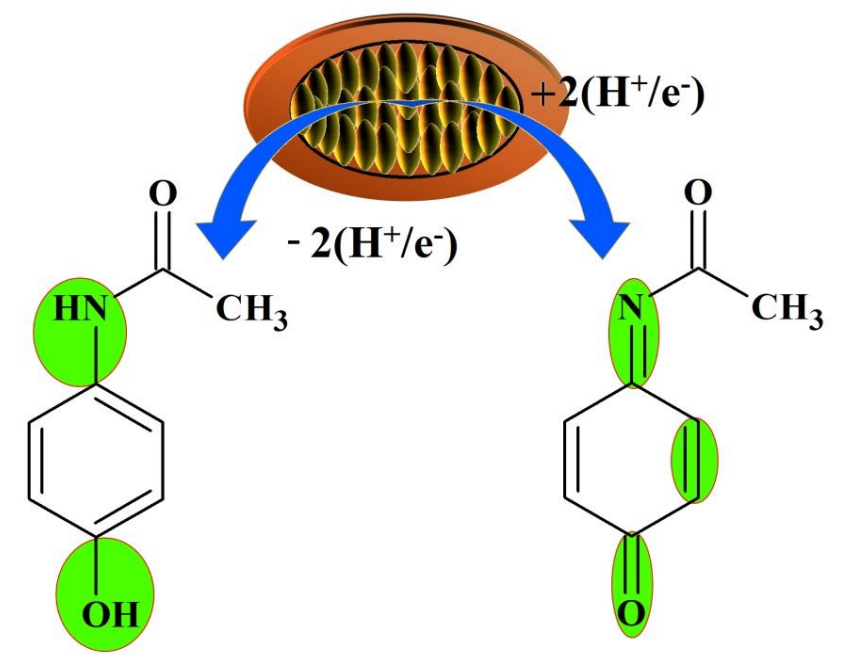

Scheme 1. Possible redox reaction of PC at electrode surface

In regard to electrochemical investigation of $\mathrm{PC}$, Charithra et al. [42] investigated the electrochemical activity of PC at carbon nanotube paste electrode (CNTPE) modified with poly (methyl orange) using CV and DPV techniques, in phosphate buffer solution (PBS) of pH 7.5. CV response produced well resolved redox peaks at 0.35 and $0.21 \mathrm{~V} v$ s. SCE, due to the diffusion (DFN) controlled redox reaction of $\mathrm{PC}$ at the electrode surface. Linearity between anodic peak current and concentration of $\mathrm{PC}$ was procured in the concentration range of $2.0 \times 10^{-6}$ to $5.0 \times 10^{-5} \mathrm{M}$ with limit of detection (LOD) of $3.8 \times 10^{-8} \mathrm{M}$. The offered sensor showed excellent stability (Sbt) of $94.0 \%$, suitable reproducibility (Rpd) (relative standard deviation (RSD) = 3.5\%) and repeatability (Rpt) (RSD = $2.2 \%$ ). The developed electrochemical sensor showed brilliant sensing performance for the determination of PC, even at simultaneous presence of dopamine (DA) and folic acid (FA). The developed electrode was successfully applied to detect PC in some pharmaceutical formulations.

In the research performed by Zhang et al. [43], a new electrochemical sensor was fabricated for the detection of PC, based on glassy carbon electrode modified with poly (caffeic acid) and $\mathrm{Zn} / \mathrm{Ni}$ ZIF-8-800. CV and DPV techniques were applied in PBS of $\mathrm{pH} 7.5$, and the fabricated electrode was additionally characterized by electrochemical impedance spectroscopy (EIS), X-ray diffraction (XRD) and scanning electron microscopy (SEM). The electrochemical reaction taking place at the electrode surface was found adsorption (ADS) controlled. The electrode exhibited good reproducible characteristic with RSD of $2.5 \%$. DPV responses were recorded by increasing the concentration of PC from $0.08 \mu \mathrm{M}$ to $1000 \mu \mathrm{M}$ and LOD was evaluated as $0.029 \mu \mathrm{M}$. The developed novel electrochemical sensor was successfully applied for the determination of PC in medicinal dosage forms, and human urine samples with satisfactory recoveries. 
The study was conducted by Gholivand and his co-researcher [44] for the determination of PC in PBS of pH 7.0 using glassy carbon electrode modified by polyluminol/functionalized multi-walled carbon nanotubes (MWCNTs) and applying CV and SWAdSV techniques. The redox reaction of PC at the electrode surface was found ADS controlled. The prepared electrode surfaces were additionally characterized by SEM and EIS techniques. Under optimized conditions, two linear concentration ranges (0.04-32.2 and 32.2-172.2 $\mu \mathrm{M}$ ) were obtained, and LOD was determined from lower concentration range as $0.025 \mu \mathrm{M}$. The prepared electrode exhibited high Sbt of $95.0 \%$, and high Rpt (RSD $=2.1 \%$ ). The applicability of projected sensors was checked by determinations of PC in serum and urine samples.

As reported by Charithra et al. [45], PC was electrochemically studied using CNTPE modified with poly (alizarin carmine) sodium lauryl sulfate, having electroactive surface area (ESA) of $0.04 \mathrm{~cm}^{2}$. CV technique was applied in PBS of $\mathrm{pH}$ 7.0. The electrode reaction was DFN controlled, and exhibited enhanced Sbt $(94.0 \%)$, Rpt (RSD $=3.5 \%)$ and Rpd (RSD $=4.1 \%)$. The proposed electrode was successfully utilized to detect PC, DA and estriol simultaneously. A fine linear fit was obtained at PC concentrations from 4.0-100 $\mu \mathrm{M}$, and LOD of 0.06 $\mu \mathrm{M}$ was accomplished. The developed sensor was effectively applied for tablet sample analysis.

The analytical characteristics of some other carbon-based sensors utilized in the study of PC and reported recently in the literature, are summarized in Table 1.

Table 1. Analytical performances of different carbon-based electrodes for PC determination

\begin{tabular}{|c|c|c|c|c|c|c|c|c|}
\hline Electrode & Method & $\mathrm{ESA}, \mathrm{cm}^{2}$ & Linear range, $\mu \mathrm{M}$ & LOD, $\mu \mathrm{M}$ & RDS & $\begin{array}{l}\text { Sbt; Rpt (RSD); } \\
\text { Rpd (RSD), \% }\end{array}$ & SA & Ref. \\
\hline $\mathrm{CH}-\mathrm{CPE}$ & SWV & 0.097 & $6.6-500$ & 0.66 & DFN & - & - & [46] \\
\hline TC8A/AuNPs/MWCNT & $\begin{array}{l}\text { DPV } \\
\text { CV }\end{array}$ & - & $\begin{array}{l}1-150 \\
1-100\end{array}$ & $\begin{array}{l}0.2 \\
0.5\end{array}$ & ADS & $85.6 ;-; 4.4$ & DA & [47] \\
\hline $\mathrm{Nf} / \mathrm{GO}-\mathrm{COOPd} / \mathrm{GCE}$ & AMP & 0.15 & $0.04-800$ & 0.012 & DFN & $97.3 ; 1.6 ; 2.81$ & - & [48] \\
\hline MWCNTs/graphite/GCE & SWV & - & $0.47-13.2$ & 0.157 & DFN & $-; 2.05 ; 1.35$ & - & [49] \\
\hline AuNPs@TC8A/GN/GCE & DPV & - & $0.5-150$ & 0.1 & - & $85 ;-; 4.4$ & $\mathrm{DA}$ & [50] \\
\hline GPUCSPE & $\mathrm{CV}$ & - & $1.00-100$ & 0.818 & - & - & - & [51] \\
\hline 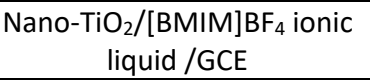 & SWV & - & $0.05-50$ & 0.01 & - & $-; 4.8 ; 5.02$ & - & {$[52]$} \\
\hline $\begin{array}{c}\text { Graphene-chitosan } \\
\text { nanocomposite/GCE }\end{array}$ & DPV & 0.124 & $1.00-100$ & 0.3 & ADS & $96.4 ; 3.0 ; 2.5$ & - & [53] \\
\hline $\mathrm{P}(4 \mathrm{ABA}) / \mathrm{ECRGO} / \mathrm{GCE}$ & DPV & 0.27 & $0.1-65$ & 0.01 & ADS & $94.8 ; 4.0 ; 3.5$ & DA & [54] \\
\hline PEDT/GOC/GCE & $\mathrm{CV}$ & - & $10-60$ & 0.57 & - & - & - & [55] \\
\hline $\begin{array}{l}\text { Graphene-modified carbon- } \\
\text { paste electrode }\end{array}$ & SWV & - & $2.5-143$ & 0.6 & ADS & - & - & [56] \\
\hline $\begin{array}{l}\text { Poly(taurine)/ } / \mathrm{TiO}_{2} \text {-graphene } \\
\text { nanocomposite/GCE }\end{array}$ & DPV & - & $0.1-90$ & 0.5 & DFN & $95.75 ; 3.29 ; .81$ & Caffeine & [57] \\
\hline Poly(caffeic acid)/GCE & SWV & - & $0.2-10$ & 0.026 & ADS & $-; 3.7 ;-$ & $\begin{array}{c}\text { AA, DA, UA, } \\
\text { p-amino } \\
\text { phenol }\end{array}$ & [58] \\
\hline $\begin{array}{l}\mathrm{Fe}_{3} \mathrm{O}_{4} @ \mathrm{SiO}_{2} \text { nanoparticles- } \\
\text { coated PDADMAC CNT/GCE }\end{array}$ & DPV & - & $10-110$ & 0.039 & - & - & - & [59] \\
\hline $\begin{array}{l}\mathrm{TiO}_{2} \text {-graphene/poly (methyl } \\
\text { red) composite film/GCE }\end{array}$ & DPV & - & $0.25-50$ & 0.025 & ADS & $96.48 ; 1.92 ; 2.82$ & - & [60] \\
\hline $\begin{array}{l}\text { MWCNT-alumina coated } \\
\text { silica nanocomposite/GCE }\end{array}$ & SWV & - & $0.05-2.0$ & 0.05 & DFN & - & - & [61] \\
\hline Nafion/TiO ${ }_{2}$-graphene/GCE & DPV & - & $1-100$ & 0.21 & ADS & $93.0 ;-; 3.6$ & $\mathrm{AA}, \mathrm{DA}$ & [62] \\
\hline Graphene/GCE & SWV & - & $0.1-20$ & 0.032 & ADS & $94.5 ;-; 4.6$ & $\mathrm{AA}, \mathrm{DA}$ & [63] \\
\hline Pencil graphite electrode & ATSDPV & - & $0.05-2.5$ & 0.025 & - &,$--; 3.1$ & - & [64] \\
\hline ERGLNiONP/GCE & DPV & - & $0.04-100$ & 0.02 & DFN & $91.4 ;-; 2.0$ & - & [65] \\
\hline SWCNT-GNH /GCE & DPV & 0.099 & $0.05-64.5$ & 0.038 & DFN & $95.0 ; 3.7 ; 2.5$ & DA & [66] \\
\hline SWCNT/CCE & DPV & - & $0.04-8.5$ & 0.025 & DFN & $98.0 ;-; 4.0$ & - & [67] \\
\hline MCNGPSCE & DPV & - & $0.02-0.1$ & 0.034 & - & - & - & [68] \\
\hline
\end{tabular}




\begin{tabular}{|c|c|c|c|c|c|c|c|c|}
\hline Electrode & Method & $\mathrm{ESA}, \mathrm{cm}^{2}$ & Linear range, $\mu \mathrm{M}$ & $\mathrm{LOD}, \mu \mathrm{M}$ & RDS & $\begin{array}{l}\text { Sbt; Rpt (RSD); } \\
\text { Rpd (RSD), \% }\end{array}$ & SA & Ref. \\
\hline RGCABE & NPV & - & $6.6-66.0$ & 0.132 & - & $98.0 ; 2.6 ;-$ & - & [69] \\
\hline $\begin{array}{c}\mathrm{N} \text {-(3,4-dihydroxyphene- } \\
\text { thyl)-3,5-dinitrobenzamide - } \\
\text { MWCNT/CPE }\end{array}$ & DPV & 0.084 & $15-270$ & 10.0 & - & $97.0 ; 2.2 ;-$ & $\begin{array}{l}\mathrm{N} \text {-acetyl } \\
\text { cystine }\end{array}$ & [70] \\
\hline GCE & DPV & - & $4-100$ & 0.36 & DFN & -; 1.39; 1.94 & - & [71] \\
\hline $\mathrm{ZrO}_{2} / \mathrm{CPE}$ & DPV & - & $1-2500$ & 0.912 & DFN & - & $\begin{array}{l}\text { FA, Noreine- } \\
\text { phrine }\end{array}$ & [72] \\
\hline $\begin{array}{l}\text { Poly(Patton and Reeder's } \\
\text { reagent) /MCPE }\end{array}$ & DPV & - & $0.7-100$ & 0.53 & - & - & - & [73] \\
\hline
\end{tabular}

CH-CPE: coffee husks modified carbon paste electrode; $\mathrm{TC}_{8} \mathrm{~A} / \mathrm{AuNPs} / \mathrm{MWCNT}$ :thiolated calix [8] arene/gold-nanoparticles/multi-walled carbon nanotubes; Nf/GO-COOPd/GCE: Nafion/graphene oxide carboxylated Pd/glassy carbon electrode; GPUCSPE: graphite-polyurethane composite/screen printed electrode; $\mathrm{p}(4 \mathrm{ABA}) / \mathrm{ECRGO}$ : poly(4-aminobenzoic acid)/electrochemically reduced graphene oxide; PEDT/GOC: poly(3,4ethylenedioxythiophene)/graphene oxide composites; PDADMAC: poly(diallyldimethylammonium chloride); AuNPs@TC8A/GN/GCE: gold nanoparticles (AuNPs) modified by thiolated calix[8]arene graphene nanosheets; ATSDPV: adsorptive transfer stripping DPV; ERGLNiONP: electrochemically reduced graphene loaded nickel oxide nanoparticles; SWCNT-GNH: single walled carbon nanotubes-graphene nanosheet hybrid; CCE: carbon ceramic electrode; MCNGPSCE: micro crystalline natural graphite polystyrene composite electrode; RGCABE: renewable glassy carbon annular band electrode; AMP: amperometry; RDS: rate determining step; SA: simultaneous analysis; AA: ascorbic acid; UA: uric acid

\section{Electrochemical determination of diclofenac}

Diclofenac (DCF), commonly designated as voltaren, is a non-steroidal anti-inflammatory drug taken to reduce inflammation and pain [74]. It is commonly given in clinical medication for the treatment of tuberculosis, urinary tract infection and menstrual pains [75]. On the other side, DCF might cause life-threatening problems, like cardiac arrest and stroke, particularly when the patient is using it for a long time. It may also trigger harmful effects on humans, such as aplastic chlorosis, gastrointestinal problems and changes in kidney and liver functions [76]. Therefore, it is essential to determine trace amounts of DCF in biotic and medication samples, for development and treatment purposes. Scheme 2 represents the redox reaction of DCF at an electrode surface.

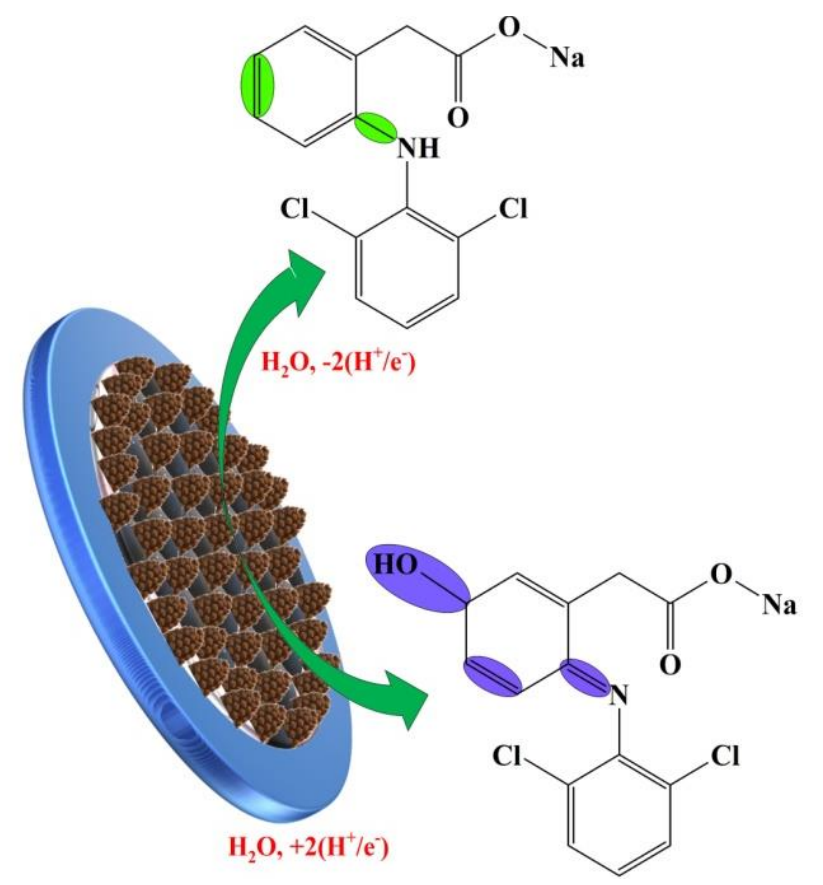

Scheme 2. Proposed redox mechanism of DCF at electrode surface

In this regard Chethana et al. [77] studied the electrochemical action of DCF using tyrosinemodified carbon paste electrode $\left(E S A=0.014 \mathrm{~cm}^{2}\right)$ by $\mathrm{CV}$ and DPV techniques in PBS of $\mathrm{pH}$ 7.0. At the prepared electrode surface, the electrochemical reaction of DCF is proceeding through DFN limited step. The resulting peak current values obtained from DPV responses were increased linearly 
within DCF concentration range from 10 to $140 \mu \mathrm{M}$, with LOD of $3.28 \mu \mathrm{M}$. The applicability of the designed sensor was checked by determinations of DCF in human urine and pharmaceutical samples with $99.5 \%$ recovery.

Altai et al. [78] developed a novel electrochemical sensor for the analysis of DCF based on f-MWCNTs and gold-platinum bimetallic nanoparticles modified gold electrode. Electrochemical properties of the fabricated sensor were evaluated by CV and DPV techniques in PBS having $\mathrm{pH}$ of 7.0, and the redox reaction at the electrode surface was found ADS controlled. The surface features of the prepared electrodes were additionally examined by SEM and energy dispersive X-ray diffraction (EDX) methods. The calibration curve of DCF was linearly fitted over the concentration range of $0.5 \mu \mathrm{M}$ to $1000 \mu \mathrm{M}$, giving LOD of $0.3 \mu \mathrm{M}$. The proposed electrode showed good Rpt (RSD $=1.7 \%)$ and Rpd (RSD $=2.6 \%)$ towards DCF determination. The prepared sensor was employed to determine DCF content in real samples.

Pushpanjali et al. [79] described poly(L-methionine) modified carbon nanotube-based platform $\left(E S A=0.043 \mathrm{~cm}^{2}\right)$ for the enhanced sensitive determination of DCF. CV and DPV techniques were used, and the electrode reaction is found ADS controlled. The developed electrodes were also characterized by field emission-SEM (FE-SEM) and (EIS) techniques. Under the optimal investigation conditions, DCF offered the linear range from $2 \mu \mathrm{M}$ and $50 \mu \mathrm{M}$ and LOD was assessed as $0.10 \mu \mathrm{M}$. The fabricated electrode showed great sensitivity, high Sbt (87.0\%), and good Rpd (RSD = 3.64 \%) and Rpt (RSD $=2.97 \%$ ). The compliance of the projected sensor was confirmed by the valuation of DFC in tablet samples.

Analytical performances of some other carbon-based electrodes recently reported in the literature for determination of DCF are summarized in Table 2.

Table 2. Analytical performances of different carbon-based electrodes for DCF determination

\begin{tabular}{|c|c|c|c|c|c|c|c|c|}
\hline Electrode & Method & $\mathrm{ESA}, \mathrm{cm}^{2}$ & Linear range, $\mu \mathrm{M}$ & LOD, $\mu \mathrm{M}$ & RDS & $\begin{array}{l}\text { Sbt; Rpt (RSD); } \\
\text { Rpd (RSD), \% }\end{array}$ & SA & Ref. \\
\hline DyNW/CPE & SWV & - & $0.01-1.0$ & 0.002 & - & - & - & [80] \\
\hline SWCNT modified EPPGE & SWV & - & $0.02-1.5$ & 0.02 & ADS & $96.18 ;-; 1.26$ & - & [81] \\
\hline EPPG & SWV & - & $0.01-1.0$ & 0.006 & ADS & - & - & [82] \\
\hline MWCNT-IL/CCE & DPV & 0.36 & $0.05-50.0$ & 0.018 & ADS & 95.0; 3.0; - & Indomethacin & [83] \\
\hline MWCNT-IL/CCE & DPV & - & $0.05-20.0$ & 0.027 & DFN & $95.0 ;-; 4.0$ & - & [84] \\
\hline $\begin{array}{l}\text { MWCNTs } / \mathrm{Cu}(\mathrm{OH})_{2} \\
\text { nanoparticles/IL }\end{array}$ & DPV & 0.012 & $0.18-119$ & 0.04 & DFN & $-; 0.99 ; 2.13$ & Naproxen & [85] \\
\hline IL/CNTPE & DPV & - & $0.50-300.0$ & 0.2 & DFN & $98.0 ; 1.5 ; 2.5$ & - & [86] \\
\hline DNA-GO/GCE & DPV & - & $1.0-130.0$ & - & DFN & - & - & [87] \\
\hline IL/MWCNTPE & SWV & 0.23 & $0.3-750$ & 0.09 & DFN & $98.0 ;-; 2.4$ & - & [88] \\
\hline CNTPE & NPV & - & $2-100$ & 0.8 & - & $-;-; 1.5$ & - & [89] \\
\hline Vinylferrocene/MWCNTPE & SWV & - & $5-600$ & 2 & - & $-; 1.9 ;-$ & Morphine & [90] \\
\hline $\begin{array}{c}\text { MWCNTs-surfactant } \\
\text { composite GCE }\end{array}$ & LSV & 0.072 & $0.17-2.5$ & 0.08 & DFN & $94.4 ; 2.10 ; 2.96$ & - & [91] \\
\hline $\begin{array}{l}\text { Cu-doped zeolite-expanded } \\
\text { graphite-epoxy electrode }\end{array}$ & DPV & - & $0.3-20$ & 0.05 & $\begin{array}{l}\text { ADS \& } \\
\text { DFN }\end{array}$ & - & - & [92] \\
\hline Ion selective electrode & PTM & - & $10-10000$ & 4.0 & - & - & - & [93] \\
\hline Bismuth film electrode & AMP & - & $6-50$ & 4.3 & - & $-; 3.27 ;-$ & - & [94] \\
\hline PEDOT/TiO 2 [BMIM]C1/CPE & DPV & - & $10-100$ & 0.011 & DFN & - & UA, AA & [74] \\
\hline $\begin{array}{l}\text { Core shell nanostructured } \\
\text { modified carbon electrode }\end{array}$ & sWV & 0.083 & $0.01-300$ & 0.034 & ADS & $97.5 ; 4.0 ; 2.4$ & - & [75] \\
\hline
\end{tabular}

DyNW: dysprosium nanowire modified; EPPGE: edge plane pyrolytic graphite electrode; IL: ionic liquid; DNA-GO: DNA- graphene oxide; PEDOT: poly(3,4-ethylene-dioxythiophene); BMIM: 1-butyl-3-methylimidazoliumchloride; PTM: potentiometry.

\section{Electrochemical scrutiny of 5-fluorouracil}

Uracil (UR) is a naturally occurring pyrimidine base found in RNA [95]. Nucleic acid biosynthesis in tumors is preferably carried out using UR. A huge number of UR derivatives are already reported 
as anti-cancer agents, among which 5-fluorouracil (5-FU) is of great importance [96]. 5-FU is amongst the most impactful drugs for the treatment of cancer, and also has antibacterial activity in a biological state [97]. However, an overdose of 5-FU has an adverse effect, including the metabolic build-up, which causes neurotoxicity and has a great impact on morbidity and mortality rates in humans. Therefore, it is necessary to determine 5-FU in pharmacological and human fluids [98]. The plausible redox mechanism of 5-FU at an electrode surface is illustrated in Scheme 3.

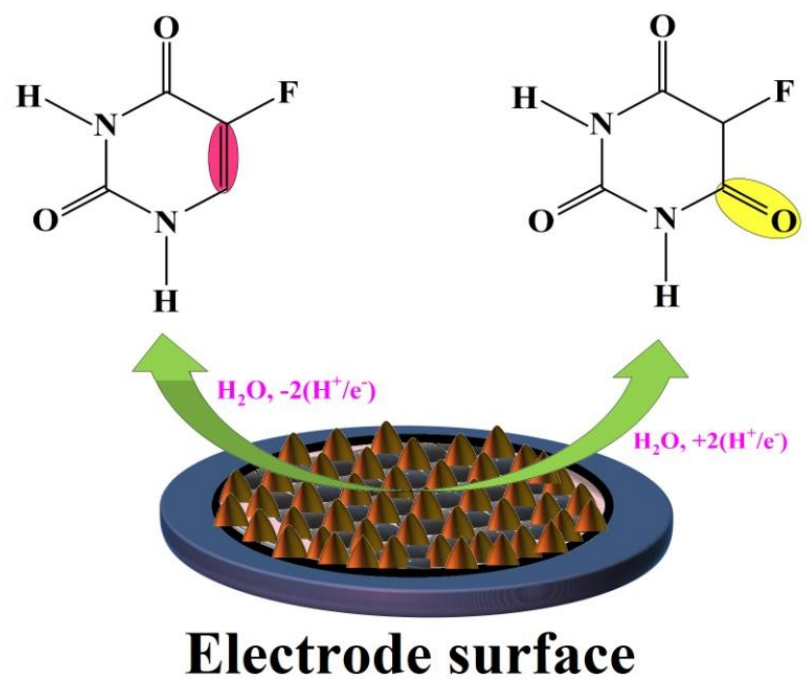

Scheme 3. Probable redox mechanism of 5-FU at electrode surface

Bukkitgar and his co-researcher [99] studied the electrochemical behavior of 5-FU at CPE modified with glucose in PBS of $\mathrm{pH}$ 7.0, using CV and DPV techniques. The redox reaction of 5-FU was found DFN controlled. The experimental results showed the applicability of electrode for electrochemical investigation of 5-FU with LOD of $0.0051 \mu \mathrm{M}$. The developed electrode exhibited good sensitivity and selectivity towards 5-FU detection. The practical application of the prepared novel electrode was demonstrated for the analysis of the pharmaceutical and urine samples.

In this context, Jyothi et al. [100] investigated 5-FU at MWCNTs - paraffin oil paste electrode $\left(E S A=0.135 \mathrm{~cm}^{2}\right)$ in PBS of $\mathrm{pH} 7.0$, using CV and DPV techniques under optimum conditions. The redox reaction of 5-FU at the electrode surface was observed to be DFN controlled. The peak current values were found linear in the concentration range from $0.1 \mu \mathrm{M}$ to $5.0 \mu \mathrm{M}$ with LOD of $0.039 \mu \mathrm{M}$. The electrode showed the outstanding selectivity and sensitivity. The proposed technique was pronounced appropriate for quality control laboratories, real sample clinical study, and pharmacokinetics.

In addition, Xin et al. [101] described glassy carbon electrode modified with bromothymol blue and MWCNTs (ESA $=0.172 \mathrm{~cm}^{2}$ ), applied in a study of the electrochemical behavior of 5-FU performed by CV method. This reaction was found controlled by ADS kinetic. The calibration graph was plotted over the logarithmic concentration range of $0.8 \mu \mathrm{M}$ to $5000 \mu \mathrm{M}$ with LOD of $0.26 \mu \mathrm{M}$. The developed method afforded the benefits of time-savings, high Rpt (RSD = 3.7 \%), high Rpd (RSD $=5.4 \%$ ) and simplicity to determine 5-FU in injection samples.

Rahimi-Nasrabadi et al. [102] constructed CPE modified with nanoparticles of praseodymium erbium tungstate $\left(E S A=0.093 \mathrm{~cm}^{2}\right.$ ) for the sensitive voltammetric detection of 5-FU, using CV and SWV techniques. This reaction was found DFN controlled. The linear 5-FU concentration range of 0.01-50 $\mu \mathrm{M}$ was used to evaluate LOD of $0.98 \mathrm{nM}$ by SWV technique. The developed novel electrode gained an excellent sensitivity, along with improved Rpd (RSD = 3.6 \%), Rpt (RSD = $1.02 \%)$ and short response time. 
Analytical properties of some other carbon-based sensors already reported in literature for the electrochemical analysis of 5-FU, are collected in Table 3.

Table 3. Analytical performances of different carbon-based electrodes for 5-FU determination

\begin{tabular}{|c|c|c|c|c|c|c|c|}
\hline Electrode & Method & $\mathrm{ESA}, \mathrm{cm}^{2}$ & $\begin{array}{c}\text { Linear } \\
\text { range, } \mu \mathrm{M}\end{array}$ & LOD, $\mu \mathrm{M}$ & RDS & $\begin{array}{c}\text { Sbt; Rpt (RSD); } \\
\text { Rpd (RSD), \% }\end{array}$ & Ref. \\
\hline Methylene blue/CPE & DPV & 0.155 & $0.1-40$ & 0.00204 & DFN & $-;-; 1.4$ & [103] \\
\hline $\mathrm{IL} / \mathrm{CPE}$ & DPV & - & $50-800$ & 0.013 & DFN & $95.9 ; 2.3 ; 3.1$ & [104] \\
\hline RGO/Chitosan/GCE & SWV & 0.192 & $0.01-0.11$ & 0.00493 & DFN & $-;-; 0.54$ & [105] \\
\hline CPE & DPV & - & $0.1-40$ & 0.01225 & DFN & $97.5 ;-; 3.5$ & {$[96]$} \\
\hline $\mathrm{ZnFe}_{2} \mathrm{O}_{4} / \mathrm{ILCPE}$ & SWV & - & $0.1-1400$ & 0.07 & DFN & $-; 3.9 ; 3.6$ & {$[97]$} \\
\hline MWCNTS/BTB/GCE & $\mathrm{CV}$ & 0.172 & $0.8-5000$ & 0.26 & - & - & [101] \\
\hline $\mathrm{GCE} / \mathrm{CTAB}$ & DPV & - & $0.02-0.6$ & 0.02013 & DFN & - & [106] \\
\hline $\begin{array}{c}\text { Porphyron/Au } \\
\text { nanoparticles/CPE }\end{array}$ & DPV & 0.075 & $29.9-234$ & 0.66 & DFN & $-; 2.09 ; 2.20$ & [107] \\
\hline GCE/p(BCP)/DNA & DPV & - & $7.6-383.8$ & 2.38 & DFN & $-; 3.9 ; 3.6$ & [108] \\
\hline $\mathrm{GQD} / \mathrm{BPBr} / \mathrm{CPE}$ & SWV & 0.26 & $0.001-400$ & 0.0005 & DFN & $92.3 ;-;-$ & [119] \\
\hline $\begin{array}{c}\text { CuNPs/MWCNT/IL/ } \\
\text { chitosan/GCE }\end{array}$ & DPV & - & $1-110$ & 0.15 & DFN & $93.0 ; 2.5 ;-$ & [110] \\
\hline PNIPAM/PEDOT/GCE & DPV & - & $0.03-182$ & $\begin{array}{l}0.015\left(40^{\circ} \mathrm{C}\right) \\
0.37\left(25^{\circ} \mathrm{C}\right)\end{array}$ & DFN & $98.6 ;-; 2.21$ & [111] \\
\hline
\end{tabular}

CPE: carbon paste electrode; RGO: reduced graphene oxide; $\mathrm{BTB}$ : bromothymolblue; CTAB: cetyltrimethyl ammonium bromide; $\mathrm{p}(\mathrm{BCP})$ : poly(bromocresol purple); GQD/BPBr: graphene quantum dots/1-butylpyridinium bromide; PNIPAM: poly(N-isopropylacrylamide)

\subsection{Electroanalysis of cetirizine}

Cetirizine (CTZ) is one of the antihistamine drugs that many people have used in medicine and pharmacy [112]. CTZ is chemically recognized as 2-[2-[4-[4-chlorophenyl]-phenylmethyl] piperazin1-yl] ethoxy] acetic acid [113]. It is usually prescribed for allergic symptoms such as runny nose, itching, hives, eye irritation, body aches, etc. [114]. However, it is understood that its overdose causes mild drowsiness, headache, dry mouth, and fatigue [115]. Therefore, it is essential to determine CTZ in biological samples. The reaction mechanism of CTZ at an electrode surface is presented in Scheme 4.

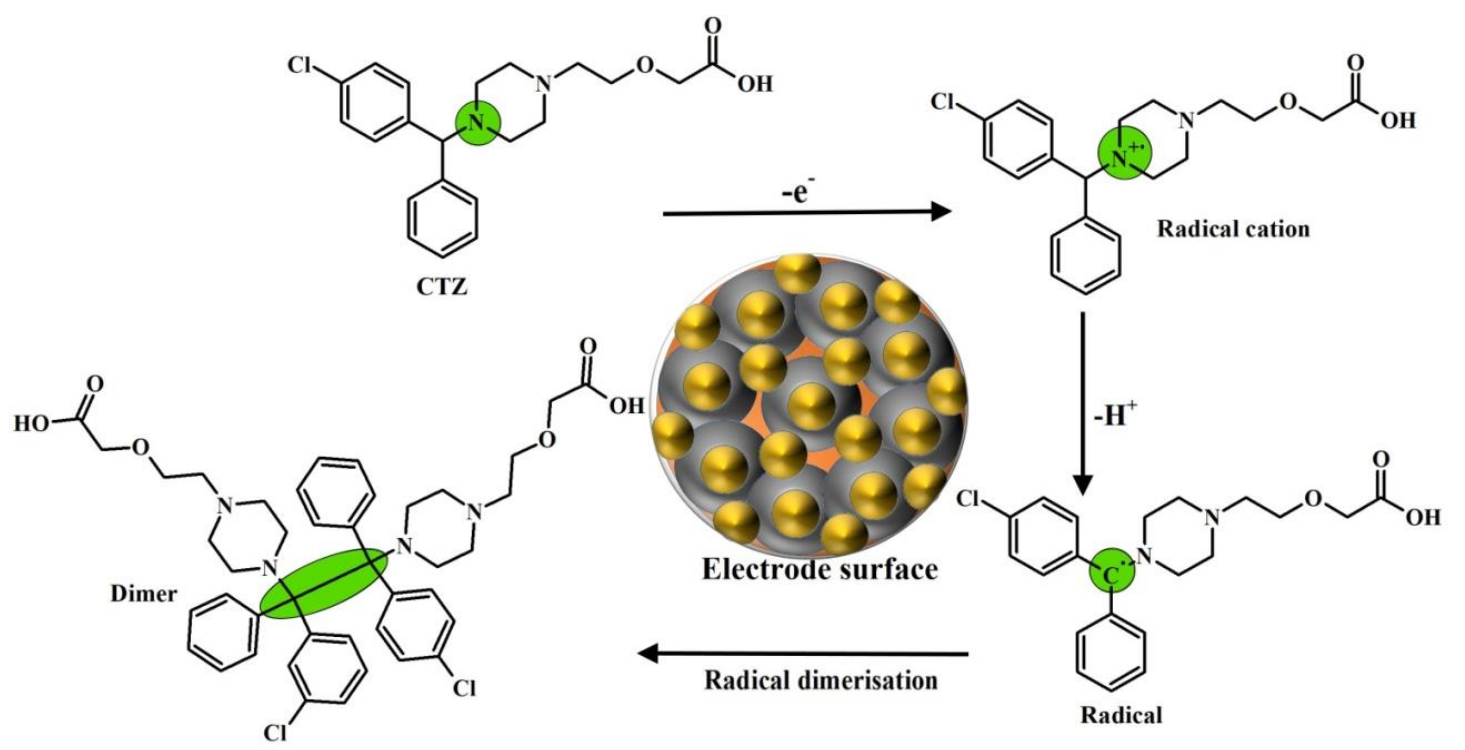

Scheme 4. Proposed reaction mechanism of CTZ at electrode surface

As reported by Girish et al. [116], CTZ was determined via CV method at poly (DL-valine) modified

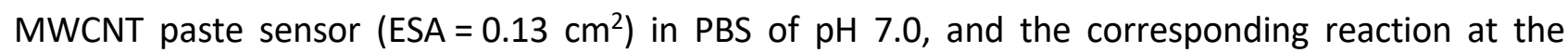
electrode surface was found DFN controlled. The fabricated sensor showed the linearity range at CTZ 
concentrations from 2.0 to $80.0 \mu \mathrm{M}$, with LOD equal to $0.11 \mu \mathrm{M}$. The fabricated sensor was fruitfully used to simultaneously detect CTZ, riboflavin and PC. The sensor surface was additionally examined by FE-SEM micrographs. The modified sensor exhibited very good Rpd (RSD = $1.24 \%$ ), Sbt (93.15 \%) and was used for the assessment of CTZ in pharmaceutical pills with satisfactory results.

Roopa et al. [117] developed MWCNTs modified GCE (ESA $\left.=0.144 \mathrm{~cm}^{2}\right)$ for the determination of the electrocatalytic activity of CTZ using CV technique, and the respective electrode reaction is found ADS controlled. LOD was evaluated by plotting the graph of peak currents versus different concentrations of $\mathrm{CTZ}$ in the range of 0.5 to $10.0 \mu \mathrm{M}$ and calculated as $0.07 \mu \mathrm{M}$. The offered technique has significant benefits over all other current methods regarding sensitivity, Rpd (RSD $=2.48 \%$ ), precision, time-saving and minimal susceptibility. The introduced sensitive and convenient electrochemical method was successfully extended to CTZ detection in pharmaceutical and urine sample trials.

The study carried out by Gholivand et al. [118] for the detection of CTZ at GCE modified with a nanocomposite of chitosan, MWCNTs and ionic liquid $\left(E S A=0.086 \mathrm{~cm}^{2}\right)$ using DPAdSV technique, showed CTZ redox reaction at the electrode surface controlled by ADS step. EIS, CV and SEM techniques were additionally used to characterize the proposed electrodes. The linear fit for CTZ determination was obtained over the concentration range of $40 \mathrm{nM}-480 \mu \mathrm{M}$, with LOD of $0.008 \mu \mathrm{M}$. The fabricated electrode showed outstanding Sbt $(96.32 \%)$, Rpt (RSD = 1.77\%), Rpd (RSD = $2.64 \%)$ and was used for the assessment of CTZ in serum and tablet as a real sample study.

Yaragatti et al. [119] have fabricated graphene oxide modified carbon paste sensor (ESA $=0.083 \mathrm{~cm}^{2}$ ) to analyze the behavior of CTZ electrochemically in PBS of pH 6.0, using CV technique. The linear response was observed in the calibration curve for concentrations of CTZ in the range of 0.01-0.4 $\mu \mathrm{M}$ with LOD of $0.0019 \mu \mathrm{M}$. The electrode reaction was found controlled by ADS step. Modification of CPE with graphene oxide particles exhibited remarkable reproducibility and accuracy.

Some already reported analytical abilities for a number of other carbon-based electrochemical sensors applied for the electrochemical investigation of CTZ are collected in Table 4.

Table 4. Analytical performances of different carbon-based electrodes for CTZ determination

\begin{tabular}{|c|c|c|c|c|c|c|c|c|}
\hline Electrode & Method & $\mathrm{ESA}, \mathrm{cm}^{2}$ & Linear range, $\mu \mathrm{M}$ & LOD, $\mu \mathrm{M}$ & RDS & $\begin{array}{l}\text { Sbt; Rpt (RSD); } \\
\text { Rpd (RSD), \% }\end{array}$ & SA & Ref. \\
\hline MWCNT/PtNPs/CPE & DPAdSV & 0.081 & $0.19-193$ & 0.058 & ADS & - & PC, Phenylephrine & [113] \\
\hline Nanoclay/CPE & SWV & 0.098 & $0.1-0.3$ & 0.00848 & ADS & - & - & [114] \\
\hline GCE & $\begin{array}{c}\mathrm{CV} \\
\mathrm{DPV}\end{array}$ & - & $20-100$ & $\begin{array}{l}4.3 \\
4.5 \\
\end{array}$ & DFN & - & - & [120] \\
\hline $\mathrm{CB} / \mathrm{GCE}$ & SWAdSV & - & $0.49-10.8$ & 0.40 & ADS & $-; 4.68 ;-$ & Hydroxyzine & [121] \\
\hline $\begin{array}{l}\text { Pretreated graphite } \\
\text { pencil electrode }\end{array}$ & SWV & - & $0.5-10$ & 0.16 & DFN & 91.7; -; - & - & [122] \\
\hline$\beta$-cyclodextrin/GCE & SWV & - & $0.02-6.0$ & 0.00037 & - & - & - & [123] \\
\hline $\mathrm{Ru}-\mathrm{TiO}_{2} / \mathrm{MWCNTs}$ & SWV & 0.042 & $0.03-1.0$ & 0.0031 & DFN & $97.0 ; 2.8 ; 2.6$ & - & [124] \\
\hline Bentonite clay/CPE & DPV & 0.083 & $0.08-1.0$ & 0.059 & DFN & $97.8 ; 2.82 ; 2.5$ & - & [125] \\
\hline $\begin{array}{c}\text { Carbon paste } \\
\text { membrane sensor }\end{array}$ & PTM & - & $0.1-60$ & 7.0 & - & $-; 0.9 ;-$ & - & [126] \\
\hline PLMCNTPE & CV & 0.039 & $5-50$ & 0.17 & DFN & $89.0 ; 3.29 ; 3.94$ & PC & [127] \\
\hline
\end{tabular}

PLMCNTPE: poly(leucine) modified carbon nanotube paste electrode

\section{Electrochemical study of salbutamol}

Salbutamol (SAL) is ([1-(4-hydroxy-3-hydroxymethylphenyl)-2-(t-butylamino) ethanol]) and is also referred as albuterol. SAL is selective agonist of $\beta 2$-adrenergic receptor widely used to treat airway obstruction in patients with bronchial asthma, emphysema, chronic obstructive pulmonary disease, lung disorders and also blood potassium level balance [128-131]. SAL is commonly used in humans as a tocolytic agent and also in veterinary medicine [132]. High doses of this medication can have a lipolytic effect. Its presence is most common in liver and meat, and it may be harmful to humans who 
are consuming those as a food supplement [133]. However, owing to its misuse as a stimulant and anabolic agent, a high dose of SAL is banned in sports. Therefore, SAL containing inhaler is permitted to use for athletes with asthma or asthma-induced exercise [134]. Hence, the determination of SAL is of high importance. The oxidation mechanism of SAL at an electrode surface is shown in Scheme 5.

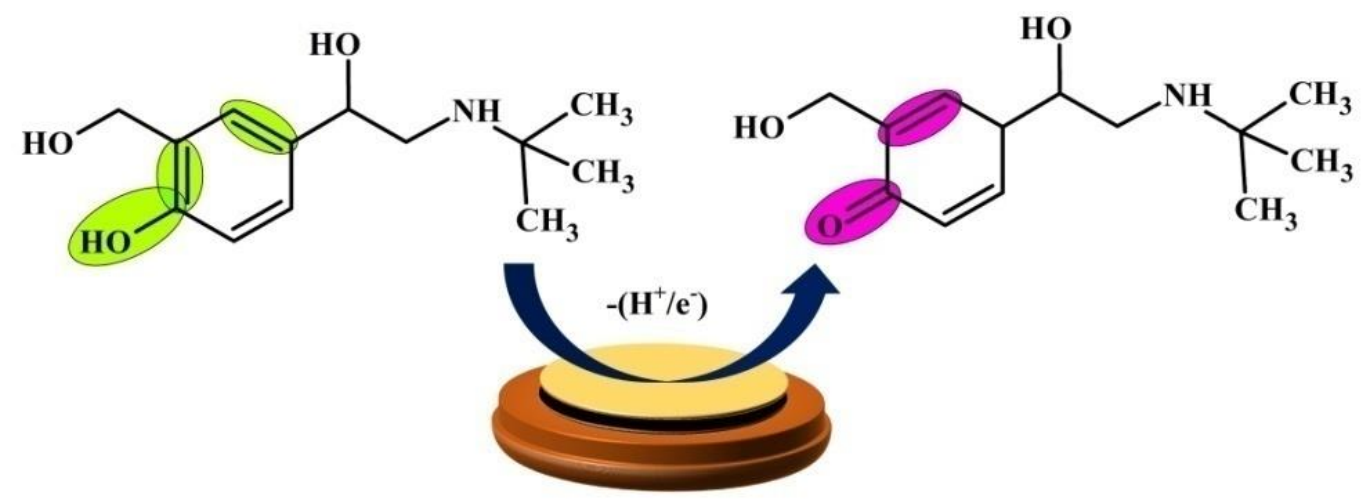

Scheme 5. Oxidation mechanism of SAL at electrode surface

Wei and his lab mates [135] determined SAL in PBS of pH 7.0 using MWCNT film coated GCE and SWV technique. The electrode reaction with respect to SAL was found ADS controlled. The response of SAL was found linear in the concentration range from $0.8 \mu \mathrm{M}$ to $10.0 \mu \mathrm{M}$ with LOD of $0.2 \mu \mathrm{M}$. The method of detecting SAL in pharmaceutical formulations was successfully carried out at the fabricated electrode. The developed electrode showed elevated Sbt (96.4\%) and Rpt (RSD = $4.2 \%)$.

A rapid and effective electrochemical method for the determination of SAL was introduced by Abdol et al. [136], using iron titanate nanopowder-modified CPE in phosphate nitrate solution having $\mathrm{pH}$ 7.5, and DPAdSV technique. The electrode exhibited a linear response for SAL in the concentration range of $0.2-25 \mathrm{nM}$ with LOD of $90 \mathrm{pM}$. The proposed electrode was found stable (90.8\%) and reproducible (RSD $4.32 \%)$. It was used satisfactorily for the detection of SAL in human serum samples.

Meareg et al. [137] determined the electrochemical behavior of SAL at poly(4-amino-3-hydroxynaphthalene) sulfonic acid modified GCE in PBS of pH 7.0 and CV technique. The electrode reaction of SAL was observed to be ADS controlled. Using DPV technique, the authors obtained the linear dependence of peak current on SAL concentration in the range of $0.2-8 \mu \mathrm{M}$, with LOD of $0.068 \mu \mathrm{M}$. The proposed method was successfully applied for the determination of SAL in medicinal dosages.

Alcian blue modified CPE for the voltammetric examination of SAL performed by CV technique was reported by Chitravathi et al. [138]. The authors gained the linearity in the concentration range of $0.5-18.0 \mu \mathrm{M}$, with LOD of $0.06 \mu \mathrm{M}$. From the scan rate study, the electrode reaction was evaluated to be DFN controlled. The proposed method was successfully extended for SAL determination in tablet samples with acceptable recovery. Also, the developed electrode was found to be highly stable (97.55\%).

Analytical properties of some other carbon-based electrochemical sensors, recently reported in the literature for the electrochemical investigation of SAL, are collected in Table 5.

Table 5. Analytical performances of different carbon-based electrodes for SAL determination

\begin{tabular}{ccccccccc}
\hline Electrode & Method & ESA, $\mathrm{cm}^{2}$ & $\begin{array}{c}\text { Linear range, } \\
\mu \mathrm{M}\end{array}$ & LOD, $\mu \mathrm{M}$ & RDS & $\begin{array}{c}\text { Sbt; Rpt (RSD); } \\
\text { Rpd (RSD), \% }\end{array}$ & SA & Ref. \\
\hline $\begin{array}{c}\text { Nano-Au/MWCNTs- } \\
\text { Nf/GCE }\end{array}$ & LSV & - & $0.09-7.0$ & 0.05 & ADS & $94.5 ; 4.6 ; 4.3$ & - & {$[139]$} \\
\hline C60/GCE & SWV & - & $0.42-8.35$ & 0.17 & DFN & - & - & {$[140]$} \\
\hline
\end{tabular}




\begin{tabular}{|c|c|c|c|c|c|c|c|c|}
\hline Electrode & Method & $\mathrm{ESA}, \mathrm{cm}^{2}$ & $\begin{array}{c}\text { Linear range, } \\
\mu \mathrm{M}\end{array}$ & LOD, $\mu \mathrm{M}$ & RDS & $\begin{array}{l}\text { Sbt; Rpt (RSD); } \\
\text { Rpd (RSD), \% }\end{array}$ & SA & Ref. \\
\hline Poly taurine $/ \mathrm{ZrO}_{2} / \mathrm{GCE}$ & LSV & - & $5-220$ & 0.02 & ADS & $-; 4.9 ; 3.12$ & Ractopamine & [141] \\
\hline SMWCNT-NF/GCE & AMP & - & $0.10-0.30$ & 0.10 & ADS & $94.7 ;-;-$ & Ractopamine & [142] \\
\hline GCE & DPV & - & $3.02-123.0$ & 0.51 & - & - & - & [128] \\
\hline Graphene-Au/GCE & DPV & - & $0.05-10.0$ & - & - & $90.9 ; 3.1 ;-$ & Epinephrine & [129] \\
\hline Graphene-NF/GCE & DPV & - & $0.4-30$ & 0.11 & DFN & $96.99 ;-; 4.09$ & Clenbuterol & [143] \\
\hline $\begin{array}{c}\text { P(aminosulfonic } \\
\text { acid)/GCE }\end{array}$ & $\mathrm{CV}$ & - & $2-100$ & 0.65 & - & $96.8 ; 1.85 ;-$ & - & [144] \\
\hline SWCNT/EPPGE & SWV & - & $0.21-10.57$ & 0.018 & DFN & $-; .94 ; 2.40$ & - & [145] \\
\hline $\mathrm{MnO}_{2} / \mathrm{RGO} @ \mathrm{Ni}$ foam & DPV & - & $0.042-1.463$ & 0.023 & - & $96.6 ; 3.5 ;-$ & Ractopamine & [146] \\
\hline NsCuHcFe-CNT/GCE & $\mathrm{CV}$ & - & $5-25$ & - & - & $70.0 ;-;-$ & - & [147] \\
\hline Pt-graphene-Pt/GCE & DPV & 0.682 & $0.03-180$ & 0.009 & DFN & $96.0 ;-; 3.06$ & - & [148] \\
\hline Graphene-PEDOT/PSS & $\mathrm{CV}$ & - & $5-550$ & 1.25 & - & $95.5 ;-; 7.5$ & - & [149] \\
\hline $\mathrm{MIP} / \mathrm{CPE}$ & DPV & - & $0.001-0.055$ & 0.0006 & - & - & - & [150] \\
\hline $\mathrm{AgPd} /$ anti-SAL/GCE & LSV & - & $0.00004-0.41$ & 0.000006 & - & $-; 4.7 ; 4.7$ & $\begin{array}{l}\text { Clenbuterol; } \\
\text { Ractopamine }\end{array}$ & [151] \\
\hline
\end{tabular}

SMWCNT: mixture of SWCNT and MWCNT; NsCuHcFe: nanostructured copper hexacyanidoferrate; PSS: poly(styrene-sulfonate).

\section{Conclusions}

This article describes some recent developments of carbon-based electrodes for their possible utilization as sensors for drug molecules. As a high-performance material, carbon and its derivatives occupy a special place in pharmaceuticals, because of their extremely beneficial properties in many ways. The purpose of this review is to demonstrate the application of carbon-based electrodes for the analysis of some drug molecules, what can be also used in proof-of-principle research studies of pharmaceutical compounds in their dosage forms and biological samples. Several forms of carbonbased electrodes have emerged over the last few years for measurements of diverse targets in biologic fluids and different dosage forms. The synergetic impact of carbon-based materials with some combination of various modifiers such as metal nanoparticles, conductive polymers, or surfactants, enhances the competence of the electrode in the electrochemical determination of bioactive and electroactive molecules. The utilization of carbon-based materials in the development of sensing electrodes is still in its infant stage. Thus, future research should be directed towards the better understanding of structural properties of carbon-based materials which administer the kinetics of electron transfer at the electrode surface and avoid formation of modifier precipitation. The unresolved questions in the electrochemistry of carbon-based electrodes still need to be solved. One between them could be formulated as: do different surface characteristics and defects present different activity, and is this related to the kind of carbon material used? The other one is: what kind of mechanism would define the electrochemical performance of an electrode? The interaction between the target analyte and functional groups present at the electrode surface needs to be explored properly.

\section{References}

[1] H. P. Rang, M. M. Dale, J. M. Ritter, R. J. Flower, G. Henderson, What is Pharmacology in Rang \& Dale's Pharmacology ( $7^{\text {th }}$ ed), Edinburgh, Churchill Livingstone, 2011. ISBN 978-0-7020-3471-8

[2] R. M. Hanabaratti, J. I. Gowda, S. M. Tuwar, International Journal of Pharmacy and Pharmaceutical Sciences 11 (2018) 81-87. https://doi.org/10.22159/iipps.2019v11i2.30648

[3] B. M. Amrutha, J. G. Manjunatha, A. S. Bhatt, ACS Omega 5 (2020) 23481-23490. https://doi.org/10.1021/acsomega.0c03517

[4] N. Hareesha, J. G. Manjunatha, B. M. Amrutha, P. A. Pushpanjali, M. M. Charithra, N. S. Prinith, Journal of Electronic Materials 50 (2021) 1230-1238. https://doi.org/10.1007/s11664-020-08616-7

[5] W. Jin, J. Zhang, Journal of Chromatography A 868 (2000) 101-107. https://doi.org/10.1016/S00219673(99)01149-8 
[6] C. Nebot, S. W. Gibb, K. G. Boyd, Analytica Chimica Acta 598 (2007) 87-94. https://doi.org/10.1016/i.aca.2007.07.029

[7] T. Pérez-Ruiz, C. Martínez-Lozano, V. Tomás, R. Galera, Journal of Pharmaceutical and Biomedical Analysis 38 (2005) 87-93. https://doi.org/10.1016/j.jpba.2004.12.014

[8] A. B. Moreira, H. P. Oliveira, T. D. Atvars, Analytica Chimica Acta 539 (2005) 257-261. https://doi.org/10.1016/j.aca.2005.03.012

[9] G. Pandey, International Journal of Biomedical and Advance Research 4 (2013) 77-82. http://dx.doi.org/10.7439/ijbar

[10] N. Hareesha, J. G. Manjunatha, Journal of Science: Advanced Materials and Devices 5 (2020) 502511. https://doi.org/10.1016/j.jsamd.2020.08.005

[11] M. Shamsipur, F. Jalali, S. Ershad, Journal of Pharmaceutical and Biomedical Analysis 37 (2005) $943-$ 947. https://doi.org/10.1016/i.jpba.2004.07.051

[12] A. B. Monnappa, J. G. Manjunatha, A. S. Bhatt, N. Hareesha, Journal of Science: Advanced Materials and Devices (2021).https://doi.org/10.1016/j.jsamd.2021.05.002

[13] P. A. Pushpanjali, J. G. Manjunatha, Electroanalysis 32 (2021) 2474-2480. https://doi.org/10.1002/elan.202060181

[14] B. M. Amrutha, J. G. Manjunatha, A. S. Bhatt, C. Raril, P. A. Pushpanjali, Physical Chemistry Research 7 (2019) 523-533. http://dx.doi.org/10.22036/pcr.2019.185875.1636

[15] N. Hareesha, J. G. Manjunatha, Journal of the Iranian Chemical Society 17 (2020) 1507-1519. https://doi.org/10.1007/s13738-020-01876-4

[16] P. A. Pushpanjali, J. G. Manjunatha, G. Tigari, S. Fattepur, Analytical and Bioanalytical Electrochemistry 12 (2020) 553-568. http://www.abechem.com/article 39221 5b4cb9d77cdb1 bfb6c48fc3dac8c7fc0.pdf

[17] A. M. Fekry, S. Gawad, R. Tammam, M. Zayed, Measurement 163 (2020) 107958. https://doi.org/10.1016/i.measurement.2020.107958

[18] P. A. Pushpanjali, J. G. Manjunatha, B. M. Amrutha, N. Hareesha, Materials Research Innovations (2020). https://doi.org/10.1080/14328917.2020.1842589

[19] H. Beitollahi, M. Safaei, S. Tajik, Journal of Electrochemical Science and Engineering 9 (2019) 27-43. http://dx.doi.org/10.5599/jese.569

[20] N. Hareesha, J. G. Manjunatha, Journal of Electroanalytical Chemistry 878 (2020) 114533. https://doi.org/10.1016/j.jelechem.2020.114533

[21] H. Beitollahi, F. Movahedifar, S. Tajik, S. Jahani, Electroanalysis 31 (2019) 1195-1203. https://doi.org/10.1002/elan.201800370

[22] P. A. Pushpanjali, J. G. Manjunatha, Physical Chemistry Research 7 (2019) 813-822. https://doi.org/10.22036/pcr.2019.198397.1663

[23] J. G. Manjunatha, C. Raril, N. S. Prinith, P. A. Pushpanjali, M. M. Charithra, G. Tigari, N. Hareesha, E. S. D'Souza, B. M. Amrutha, Handbook of Nanomaterials for Sensing Applications, Micro and Nano Technologies, Chapter 6 (2021) 105-117. https://doi.org/10.1016/B978-0-12-820783-3.00022-1

[24] H. Karimi-Maleh, K. Cellat, K. Arıkan, A. Savk, F. Karimi, F. Sen, Materials Chemistry and Physics 250 (2020) 123042. https://doi.org/10.1016/j.matchemphys.2020.123042

[25] N. Hareesha, J. G. Manjunatha, Materials Research Innovations 24 (2020) 349-362. https://doi.org/10.1080/14328917.2019.1684657

[26] J. G. Manjunatha, Heliyon 4 (2018) e00986. https://doi.org/10.1016/j.heliyon.2018.e00986

[27] J. G. Manjunatha, M. Deraman, N. H. Basri, Asian Journal of Pharmaceutical and Clinical Research 8 (2015) 48-53. https://innovareacademics.in/journals/index.php/ajpcr/article/view/3615/1795

[28] P. Zuman, FABAD Journal of Pharmaceutical Sciences 31 (2006) 97-115. http://dergi.fabad.org.tr/pdf/volum31/issue2/97-115.pdf

[29] P. A. Pushpanjali, J. G. Manjunatha, M. T. Shreenivas, ChemistrySelect 4 (2019) 13427-13433. https://doi.org/10.1002/slct.201903897

[30] B. M. Amrutha, J. G. Manjunatha, A. S. Bhatt, P. A. Pushpanjali, Journal of Food Measurement and Characterization 14 (2020) 3633-3643. https://doi.org/10.1007/s11694-020-00608-9

[31] N. S. Prinith, J. G. Manjunatha, Journal of Electrochemical Science and Engineering 10 (2020) 305315. https://doi.org/10.5599/jese. 774 
[32] C. Raril, J. G. Manjunatha, Microchemical Journal 154 (2019) 104575. https://doi.org/10.1016/i.microc.2019.104575

[33] J. G. Manjunatha, M. Deraman, Analytical and Bioanalytical Electrochemistry 9 (2017) 198-213. https://www.sid.ir/FileServer/JE/55002820170207.pdf

[34] J. G. Manjunatha, C. Raril, N. Hareesha, M. M. Charithra, P. A. Pushpanjali, G. Tigari, D. K. Ravishankar, S. C. Mallappaji, Jayarame Gowda, The Open Chemical Engineering Journal 14 (2020) 90-98. https://doi.org/10.2174/1874123102014010090

[35] E. S. D' Souza, J. G. Manjunatha, C. Raril, G. Tigari, P. A. Pushpanjali, Analytical and Bioanalytical Chemistry Research 7 (2020) 461-472. https://doi.org/10.22036/ABCR.2020.214882.1445

[36] M.-M. Titirici, R. J. White, N. Brun, V. L. Budarin, D. Sheng Su, F. del Monte, J. H. Clark, M. J. MacLachlan, Chemical Society Reviews 44 (2015) 250-290. https://doi.org/10.1039/c4cs00232f

[37] S. Nasir, M. Z. Hussein, Z. Zainal, N. A. Yusof, Materials 11 (2018) 295. https://doi.org/10.3390/ma11020295

[38] J. Deng, Y. You, V. Sahajwalla, R. K. Joshi, Carbon 96 (2016) 105-115. https://doi.org/10.1016/i.carbon.2015.09.03

[39] R. T. Kachoosangi, G. G. Wildgoose, R. G. Compton, Analytica Chimica Acta 618 (2008) 54-60. https://doi.org/10.1016/j.aca.2008.04.053

[40] S. F. Mbokou, M. Pontié, B. Razafimandimby, J. Bouchara, E. Njanja, I. Tonle Kenfack, Analytical and Bioanalytical Chemistry 408 (2016) 5895-5903. https://doi.org/10.1007/s00216-016-9704-8

[41] R. Mangaiyarkarasi, S. Premlatha, R. Khan, R. Pratibha, S. Umadevi, Journal of Molecular Liquids 319 (2020) 114255. https://doi.org/10.1016/i.molliq.2020.114255

[42] M. M. Charithra, J. G. Manjunatha, Journal of Electrochemical Science and Engineering 10 (2020) 2940. https://doi.org/10.5599/jese.717

[43] W. Zhang, S. Liu, Y. Zhang, X. Ding, B. Jiang, Y. Zhang, Biosensors and Bioelectronics131 (2019) 200206. https://doi.org/10.1016/j.bios.2019.01.069

[44] M. B. Gholivand, E. Ahmadi, Russian Journal of Electrochemistry 55 (2019) 1151-1161. https://doi.org/10.1134/S102319351912005X

[45] M. M. Charithra, J. G. Manjunatha, ChemistrySelect 5 (2020) 9323-9329. https://doi.org/10.1002/slct.202002626

[46] S. F. Mbokou, M. Pontié, J. P. Bouchara, F. M. M. Tchieno, E. Njanja, A. Mogni, P. Y. Pontalier, I. K. Tonle, International Journal of Electrochemistry 2016 (2016) 1953278. https://doi.org/10.1155/2016/1953278

[47] Y. Chen, G. Zheng, Q. Shi, R. Zhao, M. Chen, Sensors and Actuators B: Chemical 277 (2018) 289-296. https://doi.org/10.1016/j.snb.2018.09.012

[48] S. J. Saleem, M. Guler, Electroanalysis 31 (2019) 2187-2198. https://doi.org/10.1002/elan.201900287

[49] A. B. Moghaddam, A. Mohammadi, S. Mohammadi, D. Rayeji, R. Dinarvand, M. Baghi, R.B Walker, Microchimica Acta 171 (2010) 377-384. https://doi.org/10.1007/s00604-010-0445-7

[50] W. Liu, Q. Shi, G. Zheng, J. Zhou, M. Chen. Analytica Chimica Acta 1075 (2019) 81-90. https://doi.org/10.1016/j.aca.2019.05.031

[51] T. R. Saciloto, P. Cervini, E. T. Gomes Cavalheir, Analytical Letters 46 (2013) 312-322. https://doi.org/10.1080/00032719.2012.718829

[52] B. Wang, Y. Li, X. Qin, Materials Science and Engineering: C 32 (2012) 2280-2285. https://doi.org/10.1016/i.msec.2012.06.015

[53] M. Zheng, F. Gao, Q. Wang, Materials Science and Engineering: C 33 (2013) 1514-1520. https://doi.org/10.1016/j.msec.2012.12.055

[54] W. Zhu, H. Huang, X. Gao, Materials Science and Engineering: C 45 (2014) 21-28. https://doi.org/10.1016/j.msec.2014.08.067

[55] K. Catt, H. Li, X. T. Cui, Acta Biomaterialia 48 (2017) 530-540. https://doi.org/10.1016/i.actbio.2016.11.039

[56] H. Bahramipur, F. Jalali, African Journal of Pharmacy and Pharmacology 6 (2012) 1298-1305. https://doi.org/10.5897/AJPP12.212

[57] X. -Q. Xiong, K. -J. Huang, C. -X. Xu, Chemical Industry and Chemical Engineering Quarterly 19 (2013) 359-368. https://doi.org/10.2298/ciceq120325070x 
[58] H. Filik, A. A. Avan, S. Aydar, International Journal of Electrochemical Science 9 (2014) 148-160. http://www.electrochemsci.org/papers/vol9/90100148.pdf

[59] S. Zalani Sofla, M. Moradi, S. Mohammadnezhad, Journal of Applied Environmental and Biological Sciences 4 (2014) 51-56. https://www.textroad.com/pdf/JAEBS/J.\%20Appl.\%20Environ.\%20Biol.\%20Sci.,\%204(2)5156,\%202014.pdf

[60] C. -X. Xu, K. -J. Huang, Y. Fan, Journal of Molecular Liquids 165 (2012) 32-37. https://doi.org/10.1016/i.molliq.2011.10.006

[61] T. L. Lu, Y. -C. Tsai, Sensors and Actuators B: Chemical 153 (2011) 439-444. https://doi.org/10.1016/j.snb.2010.11.013

[62] Y. Fan, J. -H. Liu, H. -T. Lu, Colloids and Surfaces B: Biointerfaces 85 (2011) 289-292. https://doi.org/10.1016/j.colsurfb.2011.02.041

[63] X. Kang, J. Wang, H. Wu, Talanta 81 (2010) 754-759. https://doi.org/10.1016/j.talanta.2010.01.009

[64] A. Özcan, Y. Şahin, Analytica Chimica Acta 685 (2011) 9-14. https://doi.org/10.1016/j.aca.2010.11.004

[65] G.-T. Liu, H.-F. Chen, G.-M. Lin, P.-P. Ye, X.-P. Wang, Y.-Z. Jiao, X.-Y. Guo, Y. Wen, H.-F. Yang, Biosensors and Bioelectronics 56 (2014) 26-32. https://doi.org/10.1016/j.bios.2014.01.005

[66] X. Chen, J. Zhu, Q. Xi, W. Yang, Sensors and Actuators B: Chemical 161 (2012) 648-654. https://doi.org/10.1016/i.snb.2011.10.085

[67] B. Habibi, M. Jahanbakhshi, M. H. Pournaghiazar, Microchimica Acta 172 (2011) 147-154. https://doi.org/10.1007/s00604-010-0475-1

[68] A. R. Khaskheli, J. Fischer, J. Barek, V. Vyskočil, Sirajuddin, M. I. Bhanger, Electrochimica Acta 101 (2013) 238-242. https://doi.org/10.1016/j.electacta.2012.09.102

[69] B. Baś, A. Bugajna, M. Jakubowska, W. Reczyński, A. Smalec, Electrochimica Acta 99 (2013) 190-197. https://doi.org/10.1016/i.electacta.2013.03.122

[70] A. A. Ensafi, H. Karimi-Maleh, S. Mallakpour, M. Hatami, Sensors and Actuators B: Chemical 155 (2011) 464-472. https://doi.org/10.1016/i.snb.2010.12.048

[71] C. Engin, S. Yilmaz, G. Saglikoglu, S. Yagmur, M. Sadikoglu, International Journal of Electrochemical Science 10 (2015) 1916 -1925.

[72] M. Mazloum-Ardakani, H. Beitollahi, M. K. Amini, F. Mirkhalaf, M. Abdollahi-Alibeik, Sensors and Actuators B: Chemical 151 (2010) 243-249. https://doi.org/10.1016/j.snb.2010.09.011

[73] T. Thomas, R. J. Mascarenhas, F. Cotta, K. S. Guha, B. E. K. Swamy, P. Martis, Z. Mekhalif, Colloids and Surfaces B: Biointerfaces 101 (2013) 91-96. https://doi.org/10.1016/j.colsurfb.2012.06.020

[74] R. A. Farghali, R. A. Ahmed, A. A. Alharthi, International Journal of Electrochemical Science 13 (2018) 10390-10414. https://doi.org/10.20964/2018.11.16

[75] N. C. Honakeri, S. J. Malode, R. M. Kulkarni, N. P. Shetti, Sensors International 1 (2020) 100002. https://doi.org/10.1016/j.sintl.2020.100002

[76] G. Dowling, P. Gallo, S. Fabbrocino, L. Serpe, L. Regan, Food Additives and Contaminants 25 (2008) 1497-1508.https://doi.org/10.1080/02652030802383160

[77] B. K. Chethana, S. Basavanna, Y. Arthoba Naik, Industrial \& Engineering Chemistry Research 51 (2012) 10287-10295.https://doi.org/10.1021/ie202921e

[78] M. M. Altai, G. H. Rounaghi, B. Deiminiat, Microchemical Journal 144 (2019) 254-260. https://doi.org/10.1016/j.microc.2018.09.009

[79] P. A. Pushpanjali, J. G. Manjunatha, M. T. Srinivas, FlatChem 24 (2020) 100207. https://doi.org/10.1016/j.flatc.2020.100207

[80] P. Daneshgar, P. Norouzi, M. R. Ganjali, R. Dinarvand, A. A. Moosavi-Movahedi, Sensor 9 (2009) 7903-7918. https://doi.org/10.3390/s91007903

[81] R. N. Goyal, S. Chatterjee, A. R. S. Rana, Carbon 48 (2010) 4136-4144. https://doi.org/10.1016/j.carbon.2010.07.024

[82] R. N. Goyal, S. Chatterjee, B. Agrawal, Sensors and Actuators B: Chemical 145 (2010) 743-748. https://doi.org/10.1016/i.snb.2010.01.038

[83] K. Sarhangzadeh, A. A. Khatami, M. Jabbari, S. Bahari, Journal of Applied Electrochemistry 43 (2013) 1217-1224.https://doi.org/10.1007/s10800-013-0609-3

[84] H. Razmi, K. Sarhang-Zadeh, R. Mohammad-Rezaei, Analytical Letters 46 (2013) 1885-1896. https://doi.org/10.1080/00032719.2013.777919 
[85] M. Arvand, T. M. Gholizadeh, M. A. Zanjanchi, Materials Science and Engineering: C 32 (2012) 16821689.https://doi.org/10.1016/i.msec.2012.04.066

[86] A. A. Ensafi, M. Izadi, H. Karimi-Maleh, Ionics 19 (2013) 137-144.https://doi.org/10.1007/s11581$\underline{012-0705-0}$

[87] L. Wei, J. Borowiec, L. Zhu, J. Zhang, Journal of Solid State Electrochemistry 16 (2012) 3817-3823. https://doi.org/10.1007/s10008-012-1815-3

[88] M. Goodarzian, M. A. Khalilzade, F. Karimi, V. K. Gupta, M. Keyvanfard, H. Bagheri, M. Fouladgar, Journal of Molecular Liquids 197 (2014) 114-119. https://doi.org/10.1016/j.molliq.2014.04.037

[89] A. Ambrosi, R. Antiochia, L. Campanella, R. Dragone, I. Lavagnini, Journal of Hazardous Materials 122 (2005) 219-225. https://doi.org/10.1016/j.jhazmat.2005.03.011

[90] A. Mokhtari, H. Karimi-Maleh, A. A. Ensafi, H. Beitollahi, Sensors Actuators B: Chemical 169 (2012) 96-105. https://doi.org/10.1016/i.snb.2012.03.059

[91] X. Yang, F. Wang, S. Hu, Materials Science and Engineering: C 28 (2008) 188-194. https://doi.org/10.1016/i.msec.2006.11.006

[92] F. Manea, M. Ihos, A. Remes, G. Burtica, J. Schoonman, Electroanalysis 22 (2010) 2058-2063. https://doi.org/10.1002/elan.201000074

[93] M. Shamsipur, F. Jalali, S. Ershad, Journal of Pharmaceutical and Biomedical Analysis 37 (2005) 943947. https://doi.org/10.1016/j.jpba.2004.07.051

[94] J. A. Rodríguez, E. Barrado, Y. Castrillejo, J. R. Santos, J. L. F. C. Lima, Journal of Pharmaceutical and Biomedical Analysis 45 (2007) 47-53. https://doi.org/10.1016/i.jpba.2007.05.025

[95] R. J. Rutman, A. Cantarow, K. E. Paschkis, Cancer Research 14 (1954) 119-123. https://cancerres.aacrjournals.org/content/canres/14/2/119.full.pdf

[96] S. D. Bukkitgar, N. P. Shetti, Journal of Analytical Science and Technology 7 (2016) 1. https://doi.org/10.1186/s40543-015-0080-3

[97] A. F. Shojaei, K. Tabatabaeian, S. Shakeri, F. Karimi, Sensors and Actuators B: Chemical 230 (2016) 607-614. https://doi.org/10.1016/i.snb.2016.02.082

[98] D. K. Zeybek, B. Demir, B. Zeybek, S. Pekyardımcı, Talanta 144 (2015) 793-800. https://doi.org/10.1016/j.talanta.2015.06.077

[99] S. D. Bukkitgar, N. P. Shetti, ChemistrySelect 1 (2016) 771-777. https://doi.org/10.1002/slct.201600197

[100] C. A. Jyothi, N. P. Shetti, S. T. Nandibewoor, Synthesis and Reactivity in Inorganic, Metal-Organic, and Nano-Metal Chemistry 46 (2016) 814-820. https://doi.org/10.1080/15533174.2014.989586

[101] X. Hua. X. Hou, X. Gong, G. Shen, Analytical Methods 5 (2013) 2470-2476. https://doi.org/10.1039/c3ay40149a

[102] M. Rahimi-Nasrabadi, F. Ahmadi, H. Beigizadeh, M. S. Karimi, A. Sobhani-Nasab, Y. Joseph, H. Ehrlich, M. R. Ganjali, Microchemical Journal 154 (2020) 104654. https://doi.org/10.1016/i.microc.2020.104654

[103] S. D. Bukkitgar, N. P. Shetti, Material Science and Engineering: C 65 (2016) 262-268. https://doi.org/10.1016/j.msec.2016.04.045

[104] T. Zhan, L. Cao, W. Sun, W. Hou, Analytical Methods 3 (2011) 2651-2656. https://doi.org/10.1039/C1AY05454F

[105] V. P. Pattar, S. T. Nandibewoor, RSC Advances 5 (2015) 34292-34301. https://doi.org/10.1039/C5RA04396D

[106] S. R. Sataraddi, S. T. Nandibewoor, Der Pharma Chemica 3 (2011) 253-265.

[107] D. Lima, G. N. Calaça, A. G. Viana, C. A. Pessôa, Applied Surface Science 427 (2018) 742-753. https://doi.org/10.1016/j.apsusc.2017.08.228

[108] D. Koyuncu Zeybek, B. Demir, B. Zeybek, Ş. Pekyardımcı, Talanta 144 (2015) 793-800. https://doi.org/10.1016/j.talanta.2015.06.077

[109] R. Emamian, M. Ebrahimi, H. Karimi-Maleh, Journal of Nanostructures 10 (2020) 230-238. https://doi.org/10.22052/JNS.2020.02.004

[110] M. Roushani, Z. Saeidi, S. Hemati, M. Hosseini, Advances in Nanochemistry 1 (2019) 73-77. https://doi.org/10.22126/ANC.2019.1128

[111] B. Mutharani, P. Ranganathan, S. -M. Chen, Sensors and Actuators B: Chemical 304 (2019) 127361. https://doi.org/10.1016/j.snb.2019.127361 
[112] S. Rudaz, S. Souverain, C. Schelling, M. Deleers, A. Klomp, A. Norris, T.L. Vu, B. Ariano, J. L. Veuthey, Analytica Chimica Acta 492 (2003) 271-282. https://doi.org/10.1016/S0003-2670(03)00339-8

[113] P. K. Kalambate, A. K. Srivastava, Sensors and Actuators B: Chemical 233 (2016) 237-248. https://doi.org/10.1016/j.snb.2016.04.063

[114] R. S. Kudchi, N. P. Shetti, S. J. Malode, A. B. Todakar, Materials Today: Proceedings 18 (2019) 558565. https://doi.org/10.1016/j.matpr.2019.06.447

[115] A. Pagliara, B. Testa, P. A. Carrupt, P. Jolliet, C. Morin, D. Morin, S. Urien, J. P. Tillement, J. P. Rihoux, Journal of Medicinal Chemistry 41 (1998) 853-863.https://doi.org/10.1021/jm9704311

[116] T. Girish, J. G. Manjunatha, P. A. Pushpanjali, N. S. Prinith, D. K. Ravishankar, G. Siddaraju, Journal of Electrochemical Science and Engineering 11 (2021) 27-38.https://doi.org/10.5599/jese.934

[117] R. H. Patil, R. N. Hegde, S. T. Nandibewoor, Colloids and Surfaces B: Biointerfaces 83 (2011) 133-138. https://doi.org/10.1016/j.colsurfb.2010.11.008

[118] M. B. Gholivand, M. Shamsipur, H. Ehzari, Microchemical Journal 146 (2019) 692-700. https://doi.org/10.1016/j.microc.2019.01.068

[119] R. M. Yaragatti, S. J. Malode, N. P. Shetti, D. S. Nayak, R. M. Kulkarni, S. B. Halbhavi, A. F. Dandin, D. C. Idli, S. S. Kalmani, V. A. Randewadi, Materials Today: Proceedings 18 (2019) 780-787. https://doi.org/10.1016/j.matpr.2019.06.496

[120] S. D. Gungor, Die Pharmazie 59 (2004) 929-933.

[121] B. C. Lourencao, T. A. Silva, M. da Silva Santos, A. G. Ferreira, O. Fatibello-Filho, Journal of Electroanalytical Chemistry 807 (2017) 187-195. https://doi.org/10.1016/i.jelechem.2017.11.013

[122] S. Karakaya, D. G. Dilgin, Monatshefte Für Chemie - Chemical Monthly 150 (2019) 1003-1010. https://doi.org/10.1007/s00706-019-2384-2

[123] K. Ozturk, N. K. Bakirhan, S. A. Ozkan, B. Uslu, Current Pharmaceutical Analysis 16 (2020) 424-437. https://doi.org/10.2174/1573412915666190802165833

[124] N. P. Shetti, S. J. Malode, D. S. Nayak, K. R. Reddy, Materials Research Express 6 (2019) 115085. https://doi.org/10.1088/2053-1591/ab4b92

[125] P. R. Vernekar, N. P. Shetti, M. M. Shanbhag, S. J. Malode, R. S. Malladi, K. Raghava Reddy, Microchemical Journal 159 (2020) 105441. https://doi.org/10.1016/j.microc.2020.105441

[126] N. M. H. Rizk, S. S. Abbas, F. A. El-Sayed, A. Abo-Bakr, International Journal of Electrochemical Science 4 (2009) 396-406. http://www.electrochemsci.org/papers/vol4/4030396.pdf

[127] P. A. Pushpanjali, J. G. Manjunatha, N. Hareesha, Edwin S D' Souza, M. M. Charithra, N. S. Prinith, Surfaces and Interfaces 24 (2021) 101154. https://doi.org/10.1016/j.surfin.2021.101154

[128] Y. Wang, Y. Ni, S. Kokot, Analytical Biochemistry 419 (2011) 76-80. https://doi.org/10.1016/j.ab.2011.08.009

[129] X.-C. Guo, H.-H. Wang, X.-J. Chen, Z.-Y. Xia, W.-Y. Kang, W.-H. Zhou, International Journal of Electrochemical Science 12 (2017) 861-875.https://doi.org/10.20964/2017.02.29

[130] C. Tantucci, A. Duguet, T. Similowski, M. Zelter, J.P. Derenne, J. Milic-Emili, European Respiratory Journal 12 (1998) 799-804.https://doi.org/10.1183/09031936.98.12040799

[131] S. Keir, C. Page, D. Spina, Journal of Allergy and Clinical Immunology 110 (2002) 388-394. https://doi.org/10.1067/mai.2002.126661

[132] A. Koole, J. Bosman, J. P. Franke, R. A. De Zeeuw, Journal of Chromatography B: Biomedical Sciences and Applications 726 (1999) 149-156. https://doi.org/10.1016/S0378-4347(99)00050-X

[133] A. Halabi, C. Ferrayoli, M. Palacio, V. Dabbene, S. Palacios, Journal of Pharmaceutical and Biomedical Analysis 34 (2004) 45-51. https://doi.org/10.1016/i.japna.2003.08.020

[134] A. Pichon, N. Venisse, E. Krupka, M. C. Perault-Pochat, A. Denjean, International Journal of Sports Medicine 27 (2006) 187-192. https://doi.org/10.1055/s-2005-865627

[135] Y. Wei, Q. Zhang, C. Shao, C. Li, L. Zhang, X. Li, Journal of Analytical Chemistry 65 (2010) 398-403. https://doi.org/10.1134/S1061934810040106

[136] A. M. Attaran, M. Javanbakht, F. Fathollahi, M. Enhessari, Electroanalysis 24 (2012) 2013-2020. https://doi.org/10.1002/elan.201200293

[137] M. Amare, G. Menkir, Heliyon 3 (2017) e00417. https://doi.org/10.1016/i.heliyon.2017.e00417

[138] S. Chitravathi, B. E. K Swamy, G. P. Mamatha, B. S. Sherigara, Chemical Sensors 3 (2013) 1-8. https://doi.org/10.13140/RG.2.1.3522.0087 
[139] Y. Li, Z. Ye, P. Luo, Y. Li, B. Ye, Analytical Methods 6 (2014) 1928-1935. https://doi.org/10.1039/c3ay41758a

[140] R. N. Goyal, D. Kaur, S. P. Singh, A. K. Pandey, Talanta 75 (2008) 63-69. https://doi.org/10.1016/j.talanta.2007.10.030

[141] M. Rajkumar, Y.-S Li, S.-M. Chen, Colloids and Surfaces B: Biointerfaces 110 (2013) 242-247. https://doi.org/10.1016/i.colsurfb.2013.03.038

[142] K.-C. Lin, C.-P. Hong, S.-M. Chen, Sensors and Actuators B: Chemical 177 (2013) 428-436. https://doi.org/10.1016/i.snb.2012.11.052

[143] Y. Zhou, H. Zhang, Z. Chang, B. Ye, M. Xu, International Journal of Electrochemical Science 11 (2016) 5154 -5164. https://doi.org/10.20964/2016.06.72

[144] L. J. Li, L. B. Yu, H. Cheng, Q. F. Chen, F. M. Wu, T. Chen, X. Y. Zhu, H. X. Kong, J. L. Wu, Analytical Letters 40 (2007) 3290-3308. https://doi.org/10.1080/00032710701672772

[145] R. N. Goyal, S. Bishnoi and B. Agrawal, International Journal of Electrochemistry 2011 (2011) 373498. https://doi.org/10.4061/2011/373498

[146] M. Y. Wang, W. Zhu, L. Ma, J. J. Ma, D. E. Zhang, Z. W. Tong and J. Chen, Biosensors and Bioelectronics 78 (2016) 259-266. https://doi.org/10.1016/j.bios.2015.11.062

[147] M. Latwal, P. Chandra, S. R. Ali, Journal of Applied Electrochemistry 44 (2014) 1127-1134. https://doi.org/10.1007/s10800-014-0736-5

[148] X. F. Zhu, X. M. Duan, J. K. Xu, L. M. Lu, K. X. Zhang, H. K. Xing, Y. S. Gao, T. T. Yang, W. M. Wang, New Journal of Chemistry 40 (2016) 302-309. https://doi.org/10.1039/c5nj02278a

[149] C. Karuwan, C. Sriprachuabwong, A. Wisitsoraat, D. Phokharatkul, P. Sritongkham, A. Tuantranont, Sensors and Actuators B: Chemical 161 (2012) 549-555.https://doi.org/10.1016/j.snb.2011.10.074

[150] T. Alizadeh, L. A. Fard, Analytica Chimica Acta 769 (2013) 100-107. https://doi.org/10.1016/i.aca.2013.01.032

[151] H. Wang, Y. Zhang, H. Li, B. Du, H. M. Ma, D. Wu, Q. Wei, Biosensors and Bioelectronics 49 (2013) 14-19. https://doi.org/10.1016/i.bios.2013.04.041

(C)2021 by the authors; licensee IAPC, Zagreb, Croatia. This article is an open-access article distributed under the terms and conditions of the Creative Commons Attribution license (https://creativecommons.org/licenses/by/4.0/) 